A
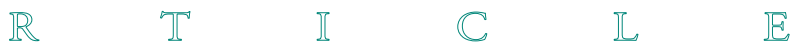

EMMANUEl LEMÉE

https://orcid.org/0000-0001-8245-8952

Sorbonne Université

\title{
THE LANGUAGE OF INCOGNITO IN LATE SEVENTEENTH-CENTURY DIPLOMACY
}

\begin{abstract}
Incognito was, by the end of the seventeenth century, a well-established and widely used practice in the European courts. In addition to its various convenience and financial uses, incognito could also have specifically diplomatic uses, acting as a unique and highly useful tool in negotiations, and it is this particular aspect of incognito this article aims to explore. Firstly, I will point out that, by suspending the standard rules governing social interactions, diplomatic incognito was first and foremost a way to free language and discourses from ceremonial restraints, which could very well be the sole and simple aim. The use of incognito did more however than simply facilitate diplomatic communications: it initiated, aside from the words spoken by the negotiators, another kind of dialogue, made of gestures and symbols, which I will endeavour to study. The last part of this article will be dedicated to the way this unique language made available using incognito could be used by early modern European states and their representatives to alter the balance of power and to level the diplomatic field in their favour.
\end{abstract}

Keywords: Early modern history; Historical anthropology; Court studies; Restoration England

Incognito was, by the end of the seventeenth century, a well-established practice. Sainctot, introducteur des ambassadeurs at the French court during Louis XIV's reign, noted for example that 'incognito is a good way to avoid the burden of all public ceremonies'. ${ }^{1}$ Indeed, in early

1 'L'incognito est bon pour éviter l'embarras de toutes les cérémonies du dehors', cited in Lucien Bély, La société des princes (Paris: Fayard, 1999), chap. XXIII. 
modern princely courts, where protocol and etiquette played a significant role, incognito was a socially acceptable way to escape the financial and symbolic burden of keeping one's rank. Incognito was a shared fiction, ${ }^{1}$ an assumed identity the public both knew to be fictional while pretending it was true. It enabled someone to assume another persona, another name, rank and status, while everyone knew the same actor remained beneath it - just like an actor changing masks. This fiction was all the more readily accepted by early modern courtiers and diplomats that, in the humanist tradition of the Renaissance, a diplomat was by nature seen as 'a maker and reader of fictions, as an exchanger of signs and constructor of narratives'. ${ }^{2}$ Standard diplomatic representation, be it extraordinary or the daily work of the resident ambassadors, was already conceived as a 'legal fiction', ${ }^{3}$ diplomats were seen both as themselves and as the sovereigns they represented. Incognito was just seen as another kind of fiction. By the end of the seventeenth century, this practice was widely known in Europe, having come to the knowledge of the Russian court, for example, as early as the 1650s. ${ }^{4}$ Every European court was therefore full of somewhat fictional characters.

The main difference between these two kinds of fictions was that incognito, by enforcing the representative's anonymity, enabled them to avoid any ceremonial or political requirements - and more particularly when the latter were deemed problematic. This social stratagem could be used regardless of one's status (high or low), thus implying very few social obligations. It was often and most notoriously used by ruling or future rulers, such as princes: one of the best-known early modern occurrences of incognito is the 'Grand Embassy' of Tsar Peter the Great.'

1 Barth Volker, Inkognito. Geschichte eines Zeremoniells (Munich: Oldenbourg Verlag, 2013).

2 Timothy Hampton, Fictions of Embassy: Literature and Diplomacy in Early Modern Europe (Ithaca, NY: Cornell University Press, 2009), p. 25.

3 Hampton, p. 165.

4 Jan Hennings, Russia and Courtly Europe: Ritual and the Culture of Diplomacy, 1648-1725 (Cambridge: Cambridge University Press, 2016), pp. 215-20.

5 For the most recent and accurate study on this journey, see Maija Jansson, 'Incognito and the New Diplomacy: The Case of Tsar Peter', MGIMO Review of International Relations, 6 (2018), 13-34; see also Bély, chap. XXIII; Hennings, pp. 160-202; Volker, pp. 101-79. 
During an eighteen-month long journey, the young tsar wandered across Western Europe 'anonymously', though without fooling anyone due to his exceptional height (six foot eight, or 203 centimetres).

Incognito was not limited to exceptional situations, and some members of early modern court society made regular use of it. Charles II of England, for example, resorted to incognito whenever he went to follow the horse races at Newmarket, even though the town was only 60 miles from Whitehall. ${ }^{6}$ During the few weeks he spent there, it was forbidden to speak to him of state matters or any other form of business as he was, to quote the French ambassador Jean-Paul de Barillon, 'as a private citizen and in the form of incognito'. ${ }^{7}$ So regular was this habit that most ambassadors, and even ministers or members of the private council, did not even bother to follow the king, knowing very well that going to Newmarket would be a waste of their time and money.

Incognito, as a concerted suspension of the rules of princely society, had multiple uses, which explained its appeal. It was used most of the times to resolve a protocol problem: incognito implied a suspension of the standard ceremonial rules, completely avoiding otherwise unsolvable questions of precedence. In 1699, Léopold, Duc de Lorraine, came incognito to Versailles under the name of Marquis de Pont-à-Mousson. He was supposed to swear fealty to Louis XIV for the Duchy of Bar. As a vassal duke, he could not claim similar ranking privileges as his wife, Élisabeth-Charlotte d'Orléans, who was a petite-fille de France. ${ }^{8}$ While she was of a higher rank than the legitimised children of the French king, Léopold was of a lower one, and could not stomach this difference of status and precedence. Incognito was chosen as the best solution: it did not offend Léopold, and at the same time avoided a complex

${ }^{6}$ He was particularly fond of horse-racing and went to Newmarket at least once a year. For the precise dates of his visits, see Brian Weiser, Charles II and the Politics of Access (Woodbridge: Boydell \& Brewer, 2003), p. 180.

7 All quotations from Correspondance Politique are the author's. Here, Archives du Ministère des Affaires Étrangères (hereafter cited as AMAE), Correspondance Politique (hereafter cited as CP) Angleterre, vol. 138, fol. 281, Jean-Paul de Barillon-d'Amoncourt to Louis XIV, London, 28 March 1680.

8 A petit-fils or petite-fille de France was the legitimate son or daughter of a fils de France, a legitimate son of a French king. 
official settlement, which would have probably involved bending the rules and creating a dangerous precedent. Élisabeth-Charlotte appeared at the French court under her real name and title, but the Duke only retained his rank, under a pseudonym; the difference in status with his wife being thus erased and his dignity remaining unharmed. ${ }^{9}$ However, the Baron de Breteuil, the then introducteur des ambassadeurs, implied that this incognito might have had another use:

This Prince has only been restored for a very short time in possession of his States, and his business is not yet in order nor good enough to sustain, without being a great inconvenience, the expenditure a ceremonial trip to the French court would have incurred. ${ }^{10}$

This was the second use of incognito: in avoiding ceremonial, European princes and their envoys also avoided the costly display of power it supposed on their part. It was, as in Léopold de Lorraine's case, particularly useful for the princes or representatives of the smaller European states, like the German and Italian states, or those struggling with money at home, like the English monarchs. Incognito could also be used to downplay the negative political fallout of a negotiation. In 1704, the Duke of Mantua was received incognito at Versailles. He was seeking the hand of Suzanne Henriette de Lorraine, whose family was under the French king's protection. However, he also had feudal obligations to the Emperor. As Louis XIV and the Emperor were embroiled in the War of the Spanish Succession (1701-14), incognito allowed the Duke to conduct his business in France without publicly failing his feudal obligations. ${ }^{11}$

Thirdly, incognito could be used to downplay an event, especially when a prince or an important court figure did not want their travels to raise attention or be given too great a significance. After all, any public figure could travel for leisure or purely personal matters, and it was not

9 Bély, chap. XXIII.

${ }_{10}$ Mémoires du baron de Breteuil, ed. Évelyne Lever (Paris: François Bourin, 1992), cited in Bély, chap. XXIII.

11 Visitors to Versailles: From Louis XIV to the French Revolution, ed. by Daniëlle Kisluk-Grosheide and Bertrand Rondot (New York: The Metropolitan Museum of Art, 2018), p. 182. 
uncommon on these occasions to choose to go incognito while at the same time retaining some informal ceremonial decorum. ${ }^{12}$

These ceremonial aspects of incognito are well-known, even if only studied by a handful of scholars. ${ }^{13}$ However, incognito had specific uses in a diplomatic context, acting as a unique and highly useful tool in negotiations, and it is this particular aspect of incognito this article aims to explore. The first section points out that, by suspending the standard rules governing social interactions, diplomatic incognito was used mainly to ease negotiations. It was an easy and agreed-upon way to free negotiators from ceremonial restraints, both in terms of language and gestures. However, incognito did more than simply facilitate diplomatic communications: the article's second section shows that it initiated another kind of dialogue made of gestures and symbols. The last section of the article examines how early modern European states and their representatives used this language of incognito to alter the balance of power and to level the diplomatic playing field in their favour.

\section{DIPLOMATIC INCOGNITO AND THE EMANCIPATION OF LANGUAGE}

An early modern European state could, of course, have material or political reasons to send a diplomat incognito rather than officially. It could be that it did not have the financial means to sustain an official embassy, or that it wanted to ensure plausible deniability if caught negotiating with some enemy of its current allies. Whatever the reasons

12 See for example André Krischer, 'Ritual Practice and Textual Representations: Free Imperial Cities in the Society of Princes', in Cultures of Diplomacy and Literary Writing in the Early Modern World, ed. by Joanna Craigwood and Tracey Sowerby (Oxford: Oxford University Press, 2019), pp. 232-34.

13 While still largely studied as a simple parenthesis in the way things normally worked at court, incognito has recently become a subject of interest in itself, largely because of the interest given by historians to gestures and material culture. See for example Gesto-immagine. Tra antico e moderno. Riflessioni sulla comunicazione non-verbale. Giornata di studio (Isernia, 18 aprile 2007), ed. by Monica Baggio and Monica Salvadori (Rome: Quasar, 2009); Hampton; on the practice of incognito see more specifically Jansson; Volker. 
behind its use, incognito always had the effect, by suspending the formal rules governing the relations between the representatives of two states, to free them from language restrictions, enabling them to speak as if they were two private citizens rather than representatives invested with an official mission.

\section{The facets of incognito}

Early modern diplomatic incognito could take different forms, yielding different effects and meanings. The present article will not dwell on the question of incognito outside of its diplomatic use: indeed, incognito was often used a simple convenience, a way to ensure privacy or to avoid money and time-consuming ceremonial for purely personal preference. Maija Jansson has shown how well-spread the practice of incognito as a convenience had become by the end of the seventeenth century, and how the meaning of the word had come to reflect the success of this practice in the wake of Westphalian negotiations. ${ }^{14}$ When used by a diplomatic actor, however, incognito was more than a simple convenience, it had a diplomatic and political meaning.

Diplomatic incognito - an identity assumed by someone tasked with a negotiation - can be defined as either complete or incomplete. Most of the time incognito remained incomplete: the envoy presented himself under a false name and impersonated a mere traveller with no diplomatic business although the court welcoming him was aware of his true identity. Being nonetheless moved by mutual interest, they acted as if they ignored the envoy's real identity and purpose. This shared public fiction ensured a comfortable and informal meeting between the negotiating parties and did not hinder at all the way business was usually run. Incomplete incognito was often used in marriage negotiations because it suited both parties' interests. Under the guise of incognito, the party initiating the negotiation could freely make enquiries about the prospective match and see them in person or via a trusted proxy. At a time when the painting was the only, and not always reliable, way to convey a person's likeness, it was sometimes prudent to check whether the future match was

14 Jansson, pp. 18-24. 
pleasant-looking and healthy. On the other hand, this use of incognito ensured that, if the negotiation fell through, the prospective match and their family did not suffer a public insult.

A complete, or real, incognito also existed, and it was the form most closely resembling the sense we give to this term today. In that case, the envoy's real identity was to be kept a complete secret, at least until the end of their mission. Sometimes in case of a successful negotiation, they would reveal their identity and make an official entry with great pomp. At other times, they would depart as discreetly as they had come, even in the case of success, without ever having disclosed their true identity to anyone, except the few select individuals they had to negotiate with. Diplomats under a real incognito did their best to stay unknown and unnoticed by the public, but often to no avail. Secrecy being almost non-existent in early modern courts, this complete incognito was rarely kept more than a few days, when it was not exposed before the diplomat's arrival. That is why the most sensitive negotiations were rarely entrusted to an envoy incognito, and preferably to a private individual who could justify a foreign trip under the pretence of personal reasons.

A way to ease negotiations via a more direct language

Whatever the degree of the incognito, its first and most visible effect was to free both parties' attitude and speech from ceremonial requirements. ${ }^{15}$ Not only the envoy could meet whomever he wanted, but he could also avoid meeting the representative of an enemy state. Most importantly, he could speak freely, without needing to mind his words before a foreign court, which an official representative had to do because his words committed the state he represented. During the negotiation of the second marriage of James, Duke of York and brother to Charles II, with the Italian princess Maria of Modena, the Earl of

${ }^{15}$ Maria Ines Aliverti, 'Le statut ambigu de l'incognito: vérité cérémonielle et vérité documentaire dans un corpus de témoignages de la fin du XVI ${ }^{\mathrm{e}}$ siècle', in La Vérité. Vérité et crédibilité: construire la vérité dans le système de communication de l'Occident (XIII $-X V I I^{e}$ siècle), ed. Jean-Philippe Genet (Paris: Éditions de la Sorbonne, 2015), pp. 303-20. 
Peterborough, the Duke's envoy, went incognito to Italy. He tells, in his memoirs ${ }^{16}$ of his arrival in Modena:

The Earl of Peterborough was received incognito to the sight and conversation of the Duchess. He was led thither the first time by Nardi alone, who fetched him up to the Palace in a private Coach, and by a back way led him up into an apartment, where he found the Duchess standing with her Back to a Table; whom he approached with the respect was due to a Sovereign Princess in her own House, she received him likewise with much courtesy, and Chairs being set, the earl began to expose the true cause of his coming, and how he was surprised to find a difficulty in a thing the World judged to be so advantageous to all the Parties. ${ }^{17}$

This encounter shows how incognito could speed up the negotiating process. The Earl was received by the Duchess Laura Martinozzi as soon as he arrived in Modena without being subjected to a long ceremonial entry. Formalities were kept to a minimum and ceremony virtually abolished, the Earl and the Duchess being seated on similar chairs despite their different ranks. The Earl, who spoke only in his own name, was able to cut immediately to the chase, criticising her openly for the way she tried to prevent the marriage. When the interview came to an end, the Duchess told the Earl his arguments had convinced her: the matter seemed to progress more in these few hours than in the preceding months. ${ }^{18}$

While late seventeenth- and early eighteenth-century European diplomacy might seem less focused on ceremony than in the sixteenth century, incognito was increasingly used as it was a reliable way to conduct negotiations informally. The practice of diplomacy had evolved so that envoys were more and more frequently chosen among competent experts rather than amongst the monarch's entourage. This made negotiations more precise and enabled envoys to broker complex settlements. Nonetheless, it also made the agreements more susceptible to be disavowed by the sovereigns upon the envoy's return. ${ }^{19}$ Incognito

16 The Earl of Peterborough wrote his personal memoirs under the guise of a treaty of genealogy, which he published under the penname of Robert Halstead.

17 Robert Halstead, Succint Genealogies... (London, 1685), p. 426.

18 Ibid., p. 427.

19 Hampton, pp. 164-65. 
appeared then as a way to test the prospective diplomatic partner and survey whether it was worth sending an official ambassador. In 1715, Philippe d'Orléans, regent on behalf of the young Louis XV, wanted to broker a peace with England. However, James Stanhope, Secretary of State for the Southern Department, had imposed three preliminary conditions the French regent could not accept without some counterpart. He sent the abbot Dubois incognito to negotiate with Stanhope to see if the English government would sign an agreement guaranteeing the Treaty of Utrecht if the French accepted these three conditions. ${ }^{20}$

Incognito was not the only option for a diplomat to speak freely: negotiators could easily, and often did, take someone aside and tell them something off the record, giving them the information needed to unlock a situation without compromising their official status as a representative by publicly divulging state secrets. Why then use incognito, which implied costly additional effort?

\section{A language of presence}

Marriages could be negotiated remotely, by using a proxy and almost every early modern European sovereign could find, in their extended family or relations, someone to play that role. However, sending someone incognito, because it represented an additional effort, sent an additional message: physical presence emphasised that the matter was important and that the sender really wanted the negotiations to succeed. Thus, incognito added a second layer of communication, this one being non-verbal and consisting of a language of physical presence.

This was why young Charles Stuart, son and heir to King James I of England, departed incognito for Spain in late February 1623 in the company of his friend the Duke of Buckingham. They both wore fake beards and pretended to be the Smith brothers. ${ }^{21}$ Their goal was to negotiate a marriage between the young prince and Infanta Maria-Anna, daughter of the Spanish king Phillip III. The 'Spanish Match' had

${ }^{20}$ Frederik Dhondt, Balance of Power and Norm Hierarchy: Franco-British Diplomacy after the Peace of Utrecht (Leiden and Boston: Brill, 2015), p. 79.

${ }^{21}$ Glyn Redworth, The Prince and the Infanta: The Cultural Politics of the Spanish Match (New Haven: Yale University Press, 2004). 
been a matter of much debate and unsuccessful negotiations for years. This trip, which exposed the heir to the English throne to the many hazards of early modern travel, was thought by the English government to be a means to end the affair swiftly, by surprising the Spanish and convincing them of their good faith. This use of incognito seemed to make a great impression upon the Spanish, who decided to accept the marriage proposal. The project was however abandoned because it no longer suited Charles' interests and triggered much parliamentary controversy in England. ${ }^{22}$ Charles and Buckingham then went to Paris, where their presence incognito signalled the French government of Louis XIII they were interested in a match with a French princess.

Incognito could thus be used to speed up and ease the negotiating process by substituting to a heavily controlled verbal communication a freer and more straightforward language, one nonetheless understood by everyone. There were of course material, mostly financial, or political reasons - such as the need to be able to deny the negotiation publicly should it become known to an important political actor opposed to it - for sending someone to negotiate incognito rather than officially. Nevertheless, as any other instrument, incognito came with its own set of rules and implications, and unavoidably sent, whether it was meant or not, a non-verbal message.

\section{INCOGNITO AS A DIPLOMATIC LANGUAGE}

This message had to be received and acknowledged - although not always positively. I will now give three examples of three different receptions of an incognito diplomat, to show how the way they were received could be used to send back a message without having to say anything apart from trivialities. Whether it was accepted, refused, or subverted, incognito always led to an answer, thus initiating a non-verbal dialogue.

22 Brennan Pursell, 'The End of the Spanish Match', Historical Journal, 45 (2002), 699-726. 
Accepting the fiction of incognito, a social necessity

As a regularly used practise in early modern Europe, people most of the time saw right through incognito: even if doubt sometimes lingered as to the precise identity of an incognito foreigner, the goal behind this visit was quickly identified. People mostly played along courteously, discreetly implying they knew what was going on but choosing to appear ignorant. In 1673, the Earl of Peterborough paid a visit to the Duke of Neuburg, whose daughter was a prospective match for the Duke of York. He managed to reach Düsseldorf and to meet the Duke incognito. However, as he tells it himself, nobody at the Duke of Neuburg's court was fooled ${ }^{23}$ : not only they complied with his incognito, but they allowed him the further honour of meeting the princess, which according to his official status he had no claim to. Giving the Earl this honour showed that the House of Neuburg was open to the match, albeit without committing to it, and that they would respond favourably if someone were to ask officially for the princess's hand on the Duke of York's behalf.

Because of this social and political necessity to recognise the fiction of incognito, this practice became fully part of diplomatic practice. Incognito, while it was a suspension of belief and a subversion of identity, was still governed by rules. One of them was that a person, having chosen to appear incognito at court or in town, could not suddenly reveal his or her real identity: this would have been a rude breach of protocol, and even Peter I, whose conduct during his Great Embassy ruffled a few feathers, only changed personas between public appearances never during them. ${ }^{24}$ This was because once a sovereign granted diplomatic recognition, it could not be rescinded. It was meant to preserve the credibility of the standard diplomatic fiction enabling sovereigns to be represented by diplomats. An exception could be made for envoys who had a valid reason to lift their incognito, especially in the wake of a successful negotiation. However, renouncing one's incognito was final. ${ }^{25}$

${ }^{23}$ Halstead, p. 421.

${ }^{24}$ Hennings, p. 180.

25 On that matter, Peter I's Great Embassy was a very specific occurrence, the Tsar being allowed to move in and out of his incognito at will, which might have been tolerated because he already appeared as an exotic and romantic figure. On this, see Hennings, pp. 160-202. 
In that way, paradoxically, incognito as 'the pretend absence of ceremony was an inverted form of ritual recognition'. ${ }^{26}$

Refusing incognito, a way to send a strong diplomatic message

Incognito thus found its diplomatic usefulness in its reception and the ensuing dialogue between both parties it triggered. Nothing, in theory, compelled the receiving court to play along, but refusing openly to acknowledge an incognito was nonetheless extremely uncommon: it was not in the spirit of civility which governed early modern European diplomatic relationships. Nonetheless, the Earl of Peterborough had to face such a refusal during the negotiations of the Duke of York's marriage. In the early summer 1673, the Duke finally chose Maria of Modena as his new wife, and the Earl immediately departed from Paris to Modena. It took him three days to reach Lyon, only to find there two gentlemen waiting to speak with him on the Duchess of Modena's behest. ${ }^{27}$

It was not uncommon, whether playfully or to test the diplomat's mood, to try an incognito by making a few strong references to the negotiation at stake. The Earl had himself been on the receiving end of this during his visit to the Duke of Neuburg. It was, however, considered improper and rude to act like the Duchess of Modena had. She had repeatedly insisted to officially recognise the Earl for who he was despite his strong efforts to stay incognito. A second one followed this first visit, and then upon the Earl's arrival at Plaisance a third, by no less than the Duchess's personal secretary. ${ }^{28}$ It was perceived as a symbolic act of violence, and it made the Earl even more uneasy to proceed because it boded poorly as to the result of his journey. Accepting his incognito showed interest in the envoy's proposal. However, the refusal to acknowledge his incognito indicated strong opposition.

In this specific case, the Duchess of Modena feared the Earl of Peterborough's arrival. She did not want to marry her daughter to the English king's brother, fearing, and rightly so, that she would be very isolated at the English court, being a Catholic and a foreigner. On the

${ }^{26}$ Ibid., p. 192.

27 Halstead, pp. 423-24.

28 Ibid., p. 424. 
contrary, the French king was bent on making this marriage happen, because it suited French interests and because marrying the heir to the English throne to a catholic princess under the protection of France would reinforce the alliance between France and England. The Duchess's domain was small, and she could not afford to displease the French king and to lose his support. She was thus compelled to approve the match. However, her personal dislike of it did not mean that she could not try to negotiate better terms for her daughter. Nevertheless, it was precisely the course of action she chose: violently shattering Peterborough's incognito would make him fear an impending failure and force him to make a few concessions to the benefit of the princess. Unfortunately, the Earl was either too loyal to comply with the Duchess's move or lacking too much in subtlety to understand it.

Subverting incognito to paralyse a negotiation

This failure did not deter the Duchess of Modena. When the Earl finally arrived in Modena, she changed her approach and sent him another message:

His Lordship advanced then privately to Modena, and about a Mile out of the Town was greeted by Nardi, the under-secretary, with a Coach and Six Horses, into which the Earl being received he was carried into the City, and set down at the Palace of $[\ldots]^{29}$ who was brother to the Bishop of Modena, of which he was put in possession in the name of the Duchess, there to remain until his Lordship should think fit to appear in public and assume his Character. The Earl [...] found there several appartments, all nobly furnished, [...] with that plenty and magnificence as at first did not please his Lordship; seeming contrary to his intentions of being private, and giving cause of discourse to Men of a proceeding that was not ordinary. ${ }^{30}$

The Earl of Peterborough's incognito was only apparently respected: he was not to be received officially at the court of Modena until he wanted to, but he was received as an official representative of the King of England, with a pomp and magnificence that gave him no hope of staying discreet.

29 The name is lacking in the original text, but it is probably the Palazzo Molza.

${ }^{30}$ Halstead, p. 426. 
Yet he could not refuse these honours without risking insulting his host or having to abandon his incognito. He was, therefore, prisoner of the palace he had been given and of his now useless incognito status. By introducing a social dissonance in the reception of the incognito Earl, the Duchess symbolically staged the diplomatic violence she was the target of: she showed her compliance with what the French king expected of her, while making it evident that she only did so under duress.

This subversion of Peterborough's incognito did, however, more than manifest the Duchess' displeasure. By blurring the Earl's status, it made his presence in Modena completely useless. Except for his first interview with the Duchess, he was never again consulted during the negotiations. He was not incognito anymore and therefore could only meet the Duchess in secret. However, she would only allow a meeting if he made an official entry which was contrary to his instructions. He was thus never again allowed in the Ducal Palace, and the marriage was arranged by the French envoy, the Marquis Dangeau, who had been sent in an official capacity. Having neutralised one of the negotiators, the Duchess could more easily drag the negotiations out, Dangeau having to continually go back to Peterborough to make sure he had his approval. In the end, the Earl felt forced to use the only weapon he had left and threatened to leave Modena without seeing the affair through. It was exactly what the Duchess wanted because it would have offered her a way to pin the blame on the English envoy, and thus to avoid the French king's wrath. Unfortunately for her, Dangeau managed to persuade Peterborough to stay long enough for him to succeed in his negotiation, but it came dangerously close to failing.

Incognito could thus be used as a powerful diplomatic tool, to send symbolic messages back and forth without having to resort to spoken or written words that could have been used against their utterer or sender. Even if this dialogue were only made of gestures, it could heavily impact negotiation and even derail it.

\section{INCOGNITO AS A LANGUAGE OF POWER}

Diplomatic incognito, and its reception, thus acted as a very efficient political index, to use a phrase coined by Robert Jervis. He used it 
to describe a gesture which had no tangible effect and carried only a symbolic meaning, but which was used to send a signal revealing an actor's real capabilities or intentions. ${ }^{31}$ To send someone incognito to negotiate something was a way to know immediately, even before words were spoken, whether the endeavour could be successful. Why was it not used more often then? As a political index, incognito was indeed very useful and versatile, maybe too much so: using incognito might have been a way to indicate something to a diplomatic partner without having to put it into words, but it also said much more, carrying with it much information about the balance of power between them and the real interests of the state using incognito.

\section{A double-edged sword}

Incognito thus presented the risk of exposing the real diplomatic and political agenda of the state using it, and this was contrary to the essence of early modern diplomacy. Early modern diplomatic actors and theoreticians thought of diplomacy as a kind of game where one had to bluff his or her partner into obtaining what one really wanted, without them ever knowing what the endgame was. ${ }^{32}$ Its disclosure was thought of as the most profound failure and a significant risk factor. Incognito was, therefore, the last resort, a tool designed for extreme situations, where success was deemed so important that taking the risk to expose one's endgame appeared as an acceptable trade-off.

As a useful way to speed up a negotiation, incognito was predominantly used in negotiations that only had a narrow time-window to succeed. Charles Stuart and Buckingham's incognito trip to Spain in 1623, for example, was a desperate attempt to cement an alliance between England and Spain. The rift between both crowns was getting broader as the Thirty Years War went on and had reached the point

31 Robert Jervis, The Logic of Images in International Relations (Princeton, NY: Princeton University Press, 1970).

32 Tilman Haug, "Negotiating with "Spirits of Brimstone and Saltpetre": Seventeenth-Century French Political Officials and Their Practices and Representations of Anger', in Discourses of Anger in the Early Modern Period, ed. by Karl A.E. Enenkel and Anita Traninger (London: Brill, 2015), pp. 381-402. 
where James I feared a war with the main catholic power in Europe was becoming inevitable. ${ }^{33}$ The Earl of Peterborough's journey across Europe that ultimately brought him to Modena was also motivated by a need for speed, and discretion. Charles II of England, who had adjourned Parliament to be able to conclude his brother's wedding freely and present it the fait accompli, was therefore put in a delicate situation. The House of Commons had made its intention to force the Duke of York to marry an English protestant clear - something the Duke could not stomach. It meant that Charles II had only a few months before Parliament reconvened in October 1673 to conclude his brother's marriage. Incognito was the perfect way for the English crown to manage this business, being both the fastest and most discreet.

Incognito, however, exposed the English state to another difficulty: by using this tool, the English admitted their weakness and, while it did not matter much to the Duke of Neuburg or the King of France who were open to a match with the Duke of York, it was immediately seen by the Duchess of Modena as a way to protect her daughter from an unwanted marriage. Using incognito in a negotiation meant losing bargaining ground because it showed all too clearly how desperate one was to conclude it satisfactorily. In that matter, Peter I's belief - from which stemmed his practice of incognito - that 'what naturally mattered was a man's inner worth, $[\ldots]$ not titles, ceremonies, or outward appearances $^{\prime 34}$ was not really shared by his contemporaries.

On the contrary, early modern diplomatic actors were convinced that to avoid ceremonial practice was an admission of one's inability to uphold it. In February 1681, following the nomination of the Earl of Conway as the new Secretary of State for the Northern Department, the Earl of Middleton, who had been sent to Austria in June 1680 to negotiate an alliance with Emperor Leopold I, received the authorisation to leave Lintz, where he resided, to follow the Emperor to Vienna incognito. ${ }^{35}$ This was intended as a compromise between Conway and

\section{Pursell.}

34 Matthew S. Anderson, Peter the Great (Harlow: Longman, 1995), p. 39, cited in Hennings, pp. 164-65.

35 Bodleian Library (hereafter cited as BL), Carte Papers, vol. 104, fol. 61v, Edward Conway to Charles Middleton, London, 8 February 1681. 
Middleton, the former wanting the ambassador to follow the Emperor everywhere. In contrast, the latter did not want to spend the significant amount of money necessary to make an official entrance in the Empire's capital. Middleton, however, bluntly refused this offer and wrote: 'In my humble opinion, it would be more for the reputation of His Majesty's affairs to have nobody here than to have one in such a manner as would discredit them'. ${ }^{36}$

This was Middleton's way to explain to the Secretary of State that the negotiation he was tasked with was not critical enough to warrant the use of a tool which would come at a heavy price in terms of prestige, and which could very well backfire. It also showed that Middleton, who was not a career diplomat, was clearly aware of all the non-spoken implications of incognito, as was the whole Austrian court, and as the Duchess of Modena had been in 1673.

Incognito was undoubtedly a useful diplomatic tool, but it was difficult to control all its implications: it said much, indeed too much, about the intentions and capabilities of a state. It was therefore used sparingly, mostly when no other option was available to conduct important business, or when negotiation was critical and simply could not fail. While it was undoubtedly a double-edged sword, it was more readily useful to smaller diplomatic actors.

\section{A useful tool for asymmetrical diplomacy}

The smaller European states had less to lose by using incognito: they were already considered weaker and often prone to financial difficulties, and it is in this spirit that the Baron de Breteuil naturally considered the Duc de Lorraine's incognito in 1699 as a mark of his lack of money. Breteuil was, as everyone in early modern Europe, naturally predisposed to associate smaller states with this kind of problems, as everyone was predisposed to think of them as more or less clients to larger states - such as France, Spain, the Holy Roman Empire, England or Sweden. Not only had these smaller states less to lose diplomatically than their larger

36 BL, Carte Papers, vol. 104, fol. 62, Charles Middleton to Edward Conway, Lintz, 15 March 1681. 
counterparts, but their size could prove very useful: they were not so much caught between a rock and a hard place than able to play the role of sovereign or client state alternatively, as they saw fit. As a sovereign state, they could send an official ambassador and demand for him to be treated with equal ceremonial deference and pomp as any other. As a client state, they could send someone incognito without breaking protocol or allegiances.

Incognito was indeed a perfect tool for smaller states, in that it compelled the larger ones to treat them as equals by suspending protocol. Thus, diplomatic incognito was rarely used by larger states. For example, France never sent an incognito diplomat to England for the whole duration of the Restoration, whereas Denmark sent three between 1670 and 1685. Most of the occurrences of diplomatic incognito were in negotiations between a large state and a smaller one, such as Modena and England in 1673, or Hanover and England in 1681. It was easier to suspend protocol in such a case because the larger state could argue that its intention was not to put too much stress on the finances of the smaller one by compelling it to give its envoy a magnificent reception. Even so, smaller states used incognito far more often than larger ones.

For a larger state, to send a diplomat incognito to a state of equal political rank would have been seen as a mark of weakness, and that is why the Earl of Middleton refused categorically to go to Vienna incognito in 1681. It could only be justified in very exceptional cases, such as Charles Stuart and Buckingham's trip to Spain in 1623. Even then this journey raised so much talk and rumours across Europe that it owed its success to careful management and political thinking from the English government, who managed to turn it around and make it appear as an incredible gesture of friendship and good faith.

While any European state could use diplomatic incognito, it could raise question regarding its diplomatic and financial capability, and encourage large states to downgrade its rank, disqualifying it as a major diplomatic power and effectively weakening it - appearances, in diplomacy, often became the truth. This made diplomatic incognito an asymmetrical tool by nature, its accepted use being for a weaker state to negotiate with a more powerful one. 


\section{An index of political power}

Diplomatic incognito was thus an inherent index of political power, and some diplomatic actors used this index to adjust their status according to their needs. Although mainly intended to lower one's rank and lessen financial and social obligations, it could also serve to increase someone's status temporarily. In January 1681, the French ambassador to England noted that the Prince of Hanover, who had come to London incognito to negotiate the hand of Princess Anne, was taking advantage of the fact that his marriage with the princess was already published everywhere as a done deal, and acted as if his rank was that of a prince of England. ${ }^{37}$ The blurring of social status created by his incognito enabled him to rise above his real rank, to persuade his partner of the necessary success of the negotiations in a sort of performative diplomacy, and more importantly to create a precedent: each mark of honour given once could be asked for at a later occasion. Even if there were little chance they would be granted, his asking for them would force his diplomatic partners to compromise. Being fully aware of the Prince's actual purpose, the Spanish ambassador complained very strongly to the King of England about the way he had been dealt with on this occasion.

Nonetheless, this subversion of status was done mostly in agreement with all involved diplomatic partners. The large states had no problem treating incognito representatives of smaller states as equals because under incognito acknowledgement of equality was not binding. ${ }^{38}$ Therefore, this situation served everyone's interests, as seen in the example of the Prince of Hanover's visit to London in 1681. Being received as an equal by the English flattered him, at no cost to Charles II because he was not bound to extend this courtesy if the Prince were to come back under his real identity. It also served to bolster the Duke of Hanover's ceremonial claims and, more importantly, allowed him to stand out amongst smaller states. The degree of courtesy or civility extended to the representatives of another state was one of the best possible indexes of power and favour. The quality of the reception given to representatives of smaller

${ }^{37}$ AMAE, CP Angleterre, vol. 142, fols 29r-v, Jean-Paul de Barillon-d'Amoncourt to Louis XIV, London, 9 January 1681.

38 Hennings, p. 180. 
states by their larger counterpart was, therefore, a way for them to gain an advantage in the competition with other smaller European states. ${ }^{39}$ For the larger states, treating the smaller ones like equals was simply an exception to an otherwise extremely rigid and strong set of social rules. This exception only served to strengthen the rules by offering a means to bypass them without having to challenge them.

\section{CONCLUSION}

Diplomatic incognito, as a political index establishing a non-verbal language of political power, was, therefore, a particularly useful diplomatic tool. It served to smooth protocol difficulties and to enable negotiations between different-size states while giving each party the impression that their rank was recognised in the most flattering manner. Far from being a breach of protocol, incognito was a ceremonial device which supplemented the formal language of official embassies and magnificent entries. It was used to express, in a socially acceptable way, the circumstantial variations of power and reflected a smaller state's bargaining power.

Incognito worked as a way of 'preserving distance, guarding status, and permitting contact among unequals through fictive concealment' ${ }^{40}$ Incognito strengthened rather than obscured the rank and status of the diplomat. Its use indicated not only a state's bargaining power but also its place on the early modern European stage. As any powerful move on such a complicated chessboard, incognito was a gambit which could alter and win an otherwise hopeless situation. However, it came with a growing cost the more important the stakes and the actors involved became. It was above all a performance. One that could not be given without an audience both at home and abroad, exceeding the court the incognito diplomat was sent to. While incognito could be kept secret for a while, it was intended to be revealed and therefore should not be mistaken for a secret kind of diplomacy - which existed but went

39 Hampton, pp. 121-22.

40 James Johnson, Venice Incognito. Masks in the Serene Republic (Oakland, California: University of California Press, 2017), p. xii. 
through other channels. Incognito was early modern diplomacy as usual: it simplified the ceremonial adding to it another layer of potentially information-laden gestures and symbols, and ultimately making it even more formal and complicated.

\section{BIBLIOGRAPHY}

\section{Archival Sources}

La Courneuve, Archives du Ministère des Affaires Étrangères

Correspondance Politique Angleterre, vols. 138, 142

Oxford, Bodleian Library

Carte Papers, Oxford, vol. 104

\section{Printed Primary Sources}

Halstead, Robert, Succinct Genealogies of the Noble and Ancient Houses of Alno, or de Alneto, Broc of Shephale, Latimer of Duntish, Drayton of Drayton, Mauduit of Werminster, Greene of Drayton, Vere of Addington, Fitz-Lewes of West-Hornedon, Howard of Effingham, and Mordaunt of Turvey. Justified by Public Records, ancient and extant Charters, Histories, and other authentick Proofs, and enriched with divers sculptures of Tombs, Images, Seals, and other Curiosities (London, 1685)

Mémoires du baron de Breteuil, ed. by Évelyne Lever (Paris: François Bourin, 1992)

\section{Secondary Works}

Aliverti, Maria Ines, 'Le statut ambigu de l'incognito: vérité cérémonielle et vérité documentaire dans un corpus de témoignages de la fin du xvie siècle', in La Vérité. Vérité et crédibilité: construire la vérité dans le système de communication de l'Occident $\left(X I I I^{e}-X V I I^{e}\right.$ siècle), ed. by Jean-Philippe Genet (Paris: Éditions de la Sorbonne, 2015), 303-20

Baggio, Monica, and Monica Salvadori, eds, Gesto-immagine. Tra antico e moderno. Riflessioni sulla comunicazione non-verbale. Giornata di studio (Isernia, 18 aprile 2007) (Rome: Quasar, 2009)

Bély, Lucien, La société des princes (Paris: Fayard, 1999)

Black, Jeremy, European International Relations 1648-1815 (Basingstoke: Palgrave, 2002)

Dhondt, Frederik, Balance of Power and Norm Hierarchy: Franco-British Diplomacy after the Peace of Utrecht (Leiden and Boston: Brill, 2015)

Hampton, Timothy, Fictions of Embassy: Literature and Diplomacy in Early Modern Europe (Ithaca, NY: Cornell University Press, 2009) 
Haug, Tilman, 'Negotiating with "Spirits of Brimstone and Saltpetre": Seventeenth-Century French Political Officials and Their Practices and Representations of Anger', in Discourses of Anger in the Early Modern Period, ed. by Karl A. E. Enenkel and Anita Traninger (London: Brill, 2015), 381-402

Hennings, Jan, Russia and Courtly Europe: Ritual and the Culture of Diplomacy, 1648-1725 (Cambridge: Cambridge University Press, 2016)

Hutton, Ronald, 'The Making of the Secret Treaty of Dover, 1668-1670', Historical Journal, 29 (1986), 297-318

Jansson, Maija, 'Incognito and the New Diplomacy: The Case of Tsar Peter', MGIMO Review of International Relations, 6 (2018), 13-34

Jervis, Robert, The Logic of Images in International Relations (Princeton, New York: Princeton University Press, 1970)

Johnson, James, Venice Incognito. Masks in the Serene Republic (Oakland, California: University of California Press, 2017)

Jones, James Rees, Britain and the World, 1649-1815 (Glasgow: Humanities Press, 1980)

Kisluk-Grosheide, Daniëlle, and Bertrand Rondot, eds, Visitors to Versailles: From Louis XIV to the French Revolution (New York: The Metropolitan Museum of Art, 2018)

Krischer, André, 'Ritual Practice and Textual Representations: Free Imperial Cities in the Society of Princes', in Cultures of Diplomacy and Literary Writing in the Early Modern World, ed. by Joanna Craigwood and Tracey Sowerby (Oxford: Oxford University Press, 2019), 232-34

Pincus, Steven, 'From Butterboxes to Wooden Shoes: The Shift in English Popular Sentiment from Anti-Dutch to Anti-French in the 1670s'; Historical Journal, 38 (1995), 333-61

Pursell, Brennan, 'The End of the Spanish Match', Historical Journal, 45 (2002), 699-726

Redworth, Glyn, The Prince and the Infanta: The Cultural Politics of the Spanish Match (New Haven: Yale University Press, 2004)

Volker, Barth, Inkognito. Geschichte eines Zeremoniells (Munich: Oldenbourg Verlag, 2013)

Emmanuel Lemée - PhD student at the Sorbonne Université; e-mail: emmanuel. lemee42@gmail.com 